\title{
Chronic effects of fire suppressors on the reproduction of the copepod Nitocra sp.
}

\author{
Efectos crónicos de los supresores de incendios sobre \\ la reproducción del copépodo Nitocra sp.
}

Maysa Ueda-De-Carvalho; Lucas Buruaem-Moreira²; Luciane Alves Maranho³ ${ }^{3}$ Denis Moledo-de-Souza-Abessa ${ }^{4}$.

\begin{tabular}{l}
\hline \multicolumn{2}{c}{ ARTICLE DATA } \\
\hline 1 Universidade Estadual Paulista, São Vicente, São \\
Paulo, Brasil. maysa.ueda@hotmail.com \\
2 Dr. Ciências Marinhas Tropicais, Universidade \\
Estadual Paulista, São Vicente, São Paulo, Brasil. \\
lburuaem@gmail.com \\
3 Ph.D. Universidade de Ribeirão Preto Boqueirão, \\
Santos, São Paulo Brasil. lucianemaranho@ \\
unisanta.br \\
4 Ph.D. Universidade Estadual Paulista, São Vicente, \\
São Paulo, Brasil. denis.abessa@unesp.br
\end{tabular}

Cite: Ueda-De-Carvalho, M., Buruaem-Moreira, L., Alves Maranho, L. \& Moledo-de-Souza-Abessa, D. (2019). Chronic effects of fire suppressors on the reproduction of the copepod Nitocra sp. Revista de Ciencias Agrícolas. 36(E): 82-94. doi: https://doi. org/10.22267/rcia.1936E.109

Received: October 102019

Accepted: November 292019

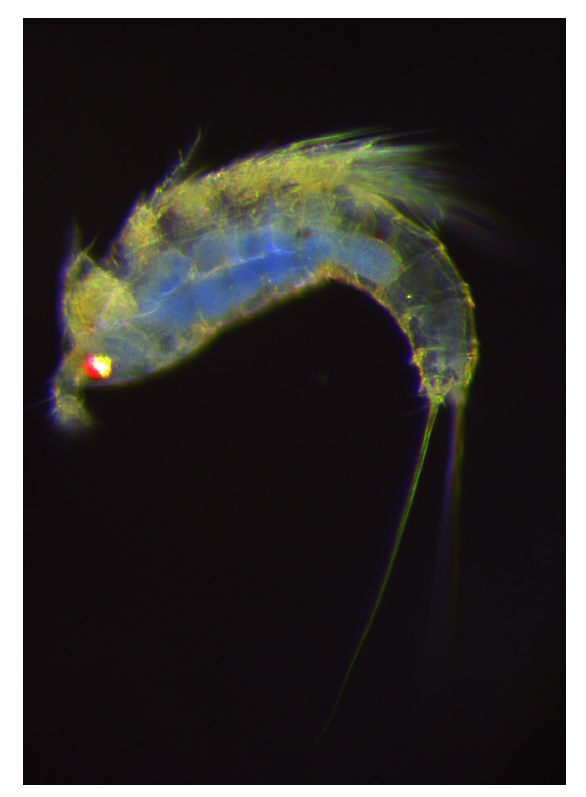

ABSTRACT

Fire suppressors are widely used in firefighting and their chemical composition may present a mixture of perfluorochlorinated surfactants (PFCs), including the perfluorooctane sulfonate (PFOS) which has been internationally banned due to its classification as a persistent organic pollutant (POP). PFCs have been found in environmental matrices and soft tissues of organisms, but the potential effect of such compounds on marine organisms has been overlooked. Here, it was evaluated whether the chronic exposures (i.e., seven days) to the fire suppressors Ageofoam, Cold Fire, Kidde and Argus could affect the reproduction of the copepod Nitocra sp. The tested concentrations consisted of those recommended on the products' manuals and those ranging between $0.0001 \%$ and $1 \%$. For each compound, the effective concentrations to $50 \%$ exposed organisms $\left(\mathrm{EC}_{50}\right)$ and the lowest observed effect concentrations (LOEC) were estimated. All the fire suppressors exhibited high toxicity, causing fecundity reduction. At the recommended dilutions, $100 \%$ lethality occurred for all compounds. The $\mathrm{EC}_{50}$ values ranged from $0.00817 \%$ - Ageofoam - to $0.03081 \%$ - Argus. The LOECs ranged from $0.001 \%$ - Ageofoam - to $0.1 \%$ Argus and Kidde; and were much lower than the concentrations recommended for commercial use. The fire suppressors showed high toxicity to the copepod, reducing the reproduction rates, even in very low concentrations, suggesting that the release of such substances in the estuary caused severe effects to the environment. This assessment provides subsides to the environmental regulation of fire suppressors in Brazil, because these compounds do not have national regulations for their use and disposal.

Key Words: ecotoxicology, aquatic organisms, pollutants, surfactants.

\section{RESUMEN}

Los supresores de incendios son usados ampliamente en la lucha contra incendios y su composición química puede presentar una mezcla de tensioactivos perfluoroclorados (PFC), incluido el sulfonato de perfluorooctano (PFOS) que ha sido prohibidos internacionalmente debido a su clasificación como un contaminante orgánico persistente (POP). Se han encontrado PFC en matrices ambientales y tejidos blandos de organismos, pero se ha pasado por alto el efecto potencial de tales compuestos en los organismos marinos. Aquí, se evaluó si las exposiciones crónicas (es decir, siete días) a los supresores de fuego Ageofoam, Cold Fire, Kidde y Argus podrían afectar la reproducción del copépodo Nitocra sp. Las concentraciones probadas consistieron en 


\begin{abstract}
las recomendadas en los manuales de los productos las cuales oscilan entre $0.0001 \%$ y $1 \%$. Para cada compuesto, se estimaron las concentraciones efectivas al 50\% de organismos expuestos (CE50) y el efecto de las concentraciones más bajas observadas (LOEC). Todos los supresores de incendios exhibieron alta toxicidad, causando una reducción de la fecundidad. A las diluciones recomendadas, se produjo un $100 \%$ de letalidad para todos los compuestos. Los valores de CE50 variaron de $0.00817 \%$ - Ageofoam - a $0.03081 \%$ - Argus. Los LOEC variaron de $0.001 \%$ - Ageofoam - a $0.1 \%$ - Argus y Kidde; y fueron mucho más bajas que las concentraciones recomendadas para uso comercial. Los supresores de incendio mostraron una alta toxicidad para el copépodo, reduciendo las tasas de reproducción, incluso en concentraciones muy bajas, lo que sugiere que la liberación de tales sustancias en el estuario causó graves efectos en el medio ambiente. Esta evaluación proporciona insumos a la regulación ambiental de los supresores de incendios en Brasil, porque estos compuestos no tienen regulaciones nacionales para su uso y eliminación.
\end{abstract}

Palabras clave: ecotoxicología, organismos acuáticos, contaminantes, surfactantes.

\section{INTRODUCTION}

Estuaries are water bodies situated at the interface between rivers, lands and seas, constituting a transition between freshwater and saline environments. Estuaries present high biological diversity and productivity. They are known for providing large amounts of food, constitute migration routes, reproduction sites and shelter for several species. In energetic terms, the complex estuarine trophic chain is often more productive than those observed in rivers and oceans, and contains enough energy to fertilize and export biomass and individuals to the open sea (Siqueira, 2006).

The Santos Estuarine System (SES) is located in the Metropolitan Region of Baixada Santista, on the central coast of the São Paulo State. The SES involves a range of ecosystems, in special broad areas occupied by mangroves, and is formed by the Santos and São Vicente Estuaries, the Santos Bay, the Bertioga Channel, and a set of inlets and smaller estuaries (SMA, 2013). The SES is inserted within a region under strong human influence, which included industrial and port activities, and presenting a severe degree of environmental degradation. This region is under high risks of chemical accidents, and at same time it is affected by large range of pollution sources, which are capable to cause acute and chronic toxicity to the local biota (Lamparelli et al., 2001; Abessa et al., 2008; Maranho et al., 2012; Buruaem et al., 2013). Aqueous Film Forming Foams (AFFFs) have been used since the 1960's decad to combat fires and recruit training in military bases, oil refineries and airports (Moody et al., 2000).

These products used worldwide are often composed by varied and complex mixtures of chemicals, in special polyfluorinated and perfluorochlorinated (PFCs) surfactants and their respective degradation products. Similarly to other persistent substances, the PFCs generally end in the aquatic environments, where they can be considered as xenobiotics, i.e. those chemical compounds strange to an organism or biological system. The PFCs can bioaccumulate and be transferred along the trophic chain, presenting a long mid-life in the environment (Montagnolli, 2015). These compounds were found in soft tissues of several marine organisms, such as fish (Benford, 2008), albatrosses, penguins and elephant seals (Tao, 2006), and also in terrestrial animals such as rats (Luebker, 2002), polar bears (Smithwick, 2005) and even in humans (Toms et al., 2014; Rotander et al., 2015). Moreover, they were also detected in food products (Benford, 2008) and environmental compartments such as groundwater, river waters (Schultz et al., 2003; Post, 2012) and air (Murakami et al., 2008). There should be highlighted that these studies evaluated some components from AFFFs, separately, and that there is very few information regarding their behavior, fate and effects when such chemicals are combined in each AFFF or between different types of AFFFs. 
The more studied AFFF component is the perfluorooctane sulfonate (PFOS), and its salts and precursors are defined as toxic and persistent, according to the Canadian Regulation of Persistence and Bioaccumulation (Minister of Justice at Canada, 2000). The PFOS is classified as a Persistent Organic Pollutant (POP), and listed in the annex B of the Stockholm Convention, which refers to those chemicals which use is restricted to the industry, and only allowed as acceptable when irreplaceable. The convention was ratified by Brazil in 2004. The Stockholm Convention requires the adoption of actions to eliminate or reduce the releases related to the production and intentional and non-intentional use of POPs. It also aims to protect the human health and the environment from the impacts caused by the exposure to toxic and persistent substances such as the PFOS. This substance is considered highly persistent in the environment and biota, affecting the reproductive systems and presenting bioaccumulation potential (Van de Vijveret et al., 2003; Hoff et al., 2005; Beach et al., 2006).

The internalization of the Stockholm Convention requirements within the national laws is made by the National Plan of Implementation, which defines the strategies and actions for attending the commitments related with the convention. Some of such strategies include improving the national analytical capability, the POPs monitoring, research and development, information dissemination and public awareness. Therefore, POPs need regulations for their industrial use, exportation and importation, commerce and use, in order to prevent human and environmental contamination (Ministério do Meio Ambiente, 2015).

Ecotoxicology is a science aimed to study the environmental contamination due to natural or synthetic pollutants of human origin, as well as their effects on the organisms (Ramade, 1977). Toxicity tests have the objective of determine and understand the effects of chemical substances present in environmental samples or prepared in laboratory on previously selected indicator organisms. Thus, experiments conducted in laboratory can provide evidences on potential in situ environmental impacts, based on responses of organisms to chemical stressors. This way, toxicity tests represent a tool for monitoring environmental pollution (De Paiva, 2008). Acute toxicity tests generally provide estimations of lethal effects, while chronic toxicity tests often evaluate non-lethal effects (Cesar et al., 1997; Azevedo \& Chasin, 2003).

Benthic copepods are used in a range of studies, to evaluate how exposure to chemical stressors can be associated to effects on reproductive success, fecundity, and development of different species, such as the genus Nitocra spp. (Izar et al., 2019; Cariello, 2018; Perina, 2018), Tisbe biminiensis (Araújo-Castro, et al., 2009; Maciel, 2015; Régis, 2018), and Amphiascus tenuiremis (Sikder, 2018; Organisation for Economic Cooperation and Development, 2007). These detritivore filter feeding organisms constitute an important component of the marine trophic chain, linking the energy and biomass flow from the primary producers to the consumers, since they represent relevant dietary items for diverse marine organisms, such as fish (special fingerlings and post larvae) and other crustaceans (Ruppert et al., 1996).

Thus, the present investigation was conducted aiming to assess the chronic toxicity of four fire suppressors Ageofoam, Cold Fire, Kidde and Argus by employing toxicity tests with the harpacticoid copepod Nitocra sp.

\section{MATERIALS AND METHODS}

This study was conducted within the context of a major fire which occurred in the Port of Santos, more precisely in fuel tanks of a petrochemical terminal localized in the interna portion of the 
port. This episode started in April $2^{\text {nd }}, 2015$ and reached enormous proportions, making it the second worst fire of this type in the world (GTCREA/SP, 2015). In the firefighting, about 61,670 liters of AFFFs were used, according to a technical note provided by the Federal Environmental Agency (Instituto Brasileiro do Meio Ambiente e dos Recursos Naturais Renováveis, 2016,). The resulting combination of the dissolved AFFFs and fuels (basically gasoline and ethanol) was discharged into the estuary. In the final phase of the firefighting, the cold fire agent was also used. This is a thermal isolator highly effective which increases the capacity of penetrating into the water, causing rapid fire extinction and a reduction of the smoke density. However, as a result, about 8 tons of dead fish were found during and after the accident. The interactions between the contaminants generated by the environmental accident and those already present in the environment put a challenge to the predictions and understanding of the complex impacts associated to this episode, as well as to the estimations of ecological risks.

AFFFs acquirement. Samples of four commercial AFFFs were provided by the Federal Environmental Agency (IBAMA). These AFFFs were used to combat the fire during the emergency in the Chemical Terminal of Aratu/Tequimar. The brands analyzed were Argus Prime L.; Ageofoam 2133; Cold Fire Fire; and Kidde Sintex Arc 1 x 3\%.

\section{Samples' preparation for the ecotoxicological} tests. With the purpose of reproducing the conditions when the AFFFs were used, the stock solutions were prepared in sea water, following the seller recommendations for each AFFF. Different concentrations were tested, aiming to determine the tolerance ranges for the testorganisms. The experiments were conducted in the Nucleus of Investigation on Aquatic Pollution and Ecotoxicology (NEPEA) from the São Paulo State University (UNESP). After preliminary tests, the lower concentration of commercial use was chosen as the highest test-concentration for each
AFFF. Other four decreasing concentrations, in logarithmic scale, were defined. The selected concentrations were $1 \%, 0.1 \%, 0.01 \%, 0.001 \%$ and $0.0001 \%$, and they prepared by diluting the stock solutions in filtered autoclaved sea water (Birge et al., 1985). Four replicates were used for each concentration of test-solution and the respective controls (clean sea water).

Nitocra sp. Test-organism. The harpacticoid copepod Nitocra sp. was used in the chronic toxicity test according to the protocol described by Lotufo and Abessa (2002). This test-organism presents a relatively short life cycle, is cosmopolite, presents high sensitivity to contaminants, is estuarine and easily cultured in laboratory. The Figure 1 shows each phase of the post embryonic development of the species. The nauplius is the first stage, followed by the copepodites (juvenile stage), and further the adult individuals; sexual dimorphism is normally evidenced by the presence of gravid females carrying egg sacs.

The test consisted of exposing five ovigerous females per chamber for seven days; food was provided only in the beginning of the test. The test chambers were kept in an incubator, under 8:16h photoperiod (light:dark) and temperature of $20 \pm$ $2^{\circ} \mathrm{C}$, without air supply. At the end of the test, the organisms were fixed and colored by the addition of a $10 \%$ formalin solution and Bengal Rode dye. The content of each chamber was gently agitated, to allow the mixture, and then left resting for at least two days. Further, the contents were analyzed under stereomicroscope, in order to identify the females (adults) and offspring (nauplii and copepodites), and evaluate the chronic toxic effects on the reduction of reproductive rates.

Statistical analysis. The concentrations of testsolutions used in the definitive tests were defined after preliminary experiments. Four replicates were used for each test-concentration and the controls. Results obtained in the toxicity tests were checked by data normality and homocedasticity $(\mathrm{p}=0.05)$; 


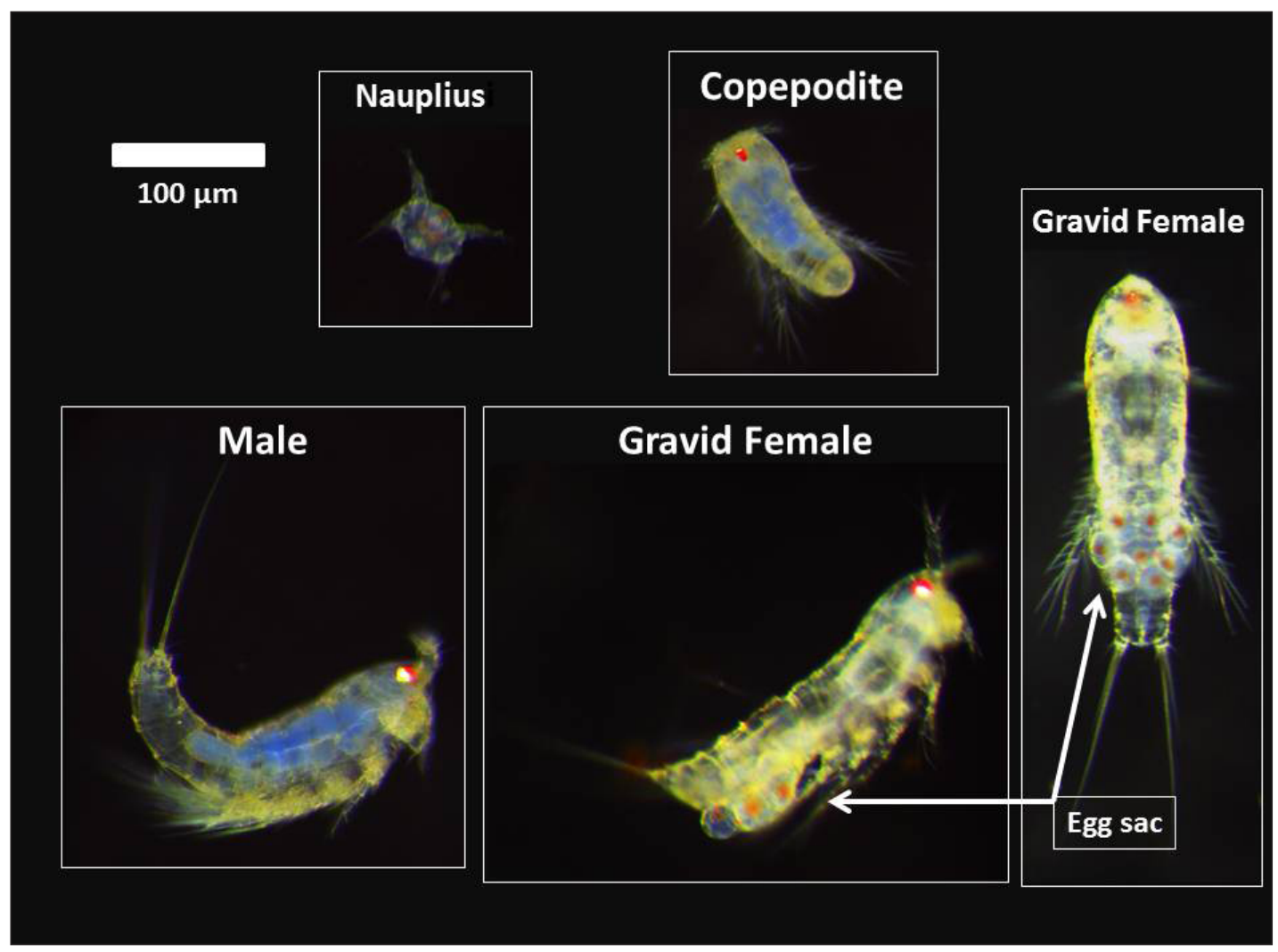

Figure 1. Micrography of the normal embryonic development of the copepod Nitocra sp.

then, a one-way Analysis of Variance (ANOVA) was applied, followed by the Dunnet's t'-test or its nonparametric equivalent in order to evaluate if the chosen endpoint presented significant differences among the AFFF concentrations and the controls.

After analyzing the endpoints that define toxicity in this study; in case, the copepods mortality and the fecundity rates, the effective concentration to $50 \%$ organisms (EC50) was calculated by using linear interpolation method. The No Effect Observed Concentration (NOEC), that is the highest tested concentration of the tested substance which does not cause deleterious effects in comparison to the controls; and the Lowest Effect Observed Concentration (LOEC), that is the lowest concentration of the tested substance capable to cause significant effect, were calculated (Cesar et al., 1997). These ecotoxicological indices were obtained by using the GraphPad Prism software, version 4.02 (GraphPad Software, Inc).

\section{RESULTS AND DISCUSSION}

During the experiments, the physical-chemical variables of the test solutions, such as dissolved oxygen (DO) levels, $\mathrm{pH}$, salinity and temperature were monitored. Their values are presented in the Table 1. These parameters tended to oscillate within the respective acceptable ranges, according to the experimental protocol (Lotufo \& Abessa, 2002). However, the $\mathrm{pH}$ values tended to present a slight reduction ( 0.5 in average), as well as the D0 levels, in all AFFFs tested; reductions of DO levels ranged between 1.0 and $2.4 \mathrm{ppt}$. 
Table 1. Physical-chemical parameters of test solutions at the beginning and final of the toxicity tests with Nitocra sp. D.0. = dissolved oxygen values.

\begin{tabular}{|c|c|c|c|c|c|c|c|c|c|c|c|c|c|}
\hline \multirow{3}{*}{ AFFF } & \multirow{3}{*}{ Parameter } & \multicolumn{12}{|c|}{ Concentrations } \\
\hline & & \multicolumn{2}{|c|}{$0 \%$} & \multicolumn{2}{|c|}{$0.0001 \%$} & \multicolumn{2}{|c|}{$0.001 \%$} & \multicolumn{2}{|c|}{$0.01 \%$} & \multicolumn{2}{|c|}{$0.1 \%$} & \multicolumn{2}{|c|}{$1 \%$} \\
\hline & & Initial & Final & Initial & Final & Initial & Final & Initial & Final & Initial & Final & Initial & Final \\
\hline \multirow{4}{*}{ Argus } & $\mathrm{pH}$ & 7.42 & 7.09 & 7.43 & 6.91 & 7.31 & 6.82 & 7.22 & 6.63 & 7.25 & 6.7 & 7.31 & 6.59 \\
\hline & D.O. (ppt) & 7.1 & 6.0 & 7.1 & 5.4 & 7.4 & 5.8 & 7.3 & 6.0 & 7.2 & 6.2 & 7.1 & 4.7 \\
\hline & Salinity & 17 & 20 & 17 & 20 & 17 & 20 & 17 & 20 & 17 & 20 & 17 & 20 \\
\hline & $\mathrm{pH}$ & 7.07 & 6.16 & 7.13 & 6.16 & 7.10 & 6.63 & 7.15 & 6.47 & 7.21 & 6.60 & 7.41 & 6.57 \\
\hline \multirow{3}{*}{ Ageofoam } & D.O. (ppt) & 6.6 & 5.8 & 6.3 & 5.6 & 6.0 & 5.5 & 6.3 & 5.5 & 6.5 & 5.3 & 6.0 & 5.4 \\
\hline & Salinity & 17 & 17 & 17 & 17 & 17 & 16 & 17 & 15 & 17 & 15 & 17 & 15 \\
\hline & $\mathrm{pH}$ & 7.13 & 6.51 & 7.0 & 6.83 & 6.82 & 7.02 & 6.83 & 7.04 & 6.78 & 7.05 & 6.78 & 6.94 \\
\hline \multirow{3}{*}{ Cold } & D.O. (ppt) & 6.5 & 6.5 & 6.3 & 6.2 & 6.4 & 6.4 & 6.5 & 6.4 & 6.5 & 6.3 & 6.5 & 6.2 \\
\hline & Salinity & 17 & 18 & 17 & 18 & 18 & 19 & 18 & 23 & 18 & 20 & 16 & 19 \\
\hline & $\mathrm{pH}$ & 7.37 & 7.96 & 7.4 & 7.9 & 7.0 & 7.2 & 7.1 & 7.4 & 7.1 & 7.02 & 7.6 & 5.02 \\
\hline \multirow{2}{*}{ Kidde } & D.0. (ppt) & 6.5 & 6.1 & 5.7 & 6.3 & 5.8 & 6.5 & 5.8 & 6.5 & 5.7 & 6.4 & 5.9 & 6.7 \\
\hline & Salinity & 18 & 20 & 18 & 21 & 18 & 21 & 18 & 20 & 17 & 20 & 17 & 24 \\
\hline
\end{tabular}

The AFFFs concentrations which caused negative effects on the reproduction of $50 \%$ exposed organisms (EC50) as well as the NOECs and LOECs are presented below (Table 2 and Figure 2). In the chronic toxicity test with Nitocra sp., the reproduction was the responsive endpoint, as the fecundity (i.e. the number of offspring produced by ovigerous female) of exposed organisms decreased.
As observed in the Figure 2, the AFFFs Ageofoam and Cold caused a uniform reduction of the fecundity along the increase of the concentrations of the toxic substance. For the other two AFFFs (Kidde and Argus) the reduction was not uniform, and from $0.1 \%$ dilution no reproduction was observed.

Table 2. Effective concentrations to 50\% exposed Nitocra sp. (EC50-7days) to AFFFs (in terms of inhibition of fecundity), and the respective No Observed Effect Concentrations (NOECs) and Lowest Observed Effect Concentrations (LOECs).

\begin{tabular}{cclccc}
\hline \multirow{2}{*}{ AFFF } & \multirow{2}{*}{ EC50 (\%) } & \multicolumn{2}{l}{$\mathbf{9 5 \% \text { Confidence Intervals }}$} & LOEC & NOEC \\
\cline { 3 - 6 } & & Superior & Inferior & $\mathbf{( \% )}$ & $\mathbf{( \% )}$ \\
\hline Ageofoam & 0.00817 & 0.01742 & 0.00038 & 0.001 & 0.0001 \\
Cold & 0.00358 & 0.00725 & 0.00017 & 0.01 & 0.001 \\
Kidde & 0.02326 & 0.05052 & 0.0107 & 0.1 & 0.01 \\
Argus & 0.03081 & 0.07441 & 0.00127 & 0.1 & 0.01 \\
\hline
\end{tabular}

Significant concentrations to the controls were determined when $\mathrm{p}<0.05$. 
Argus

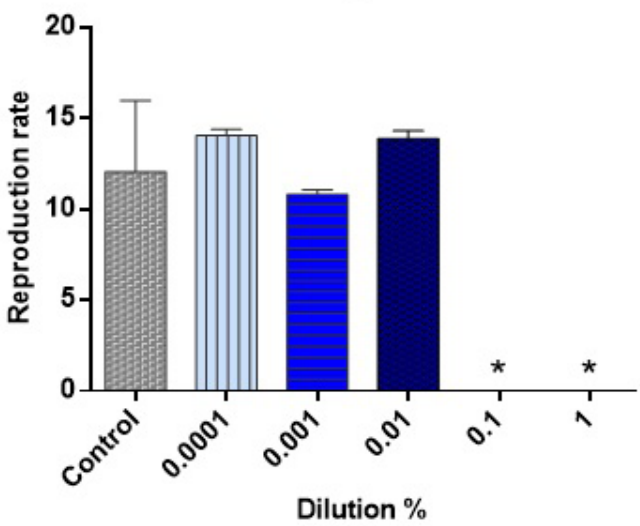

Cold

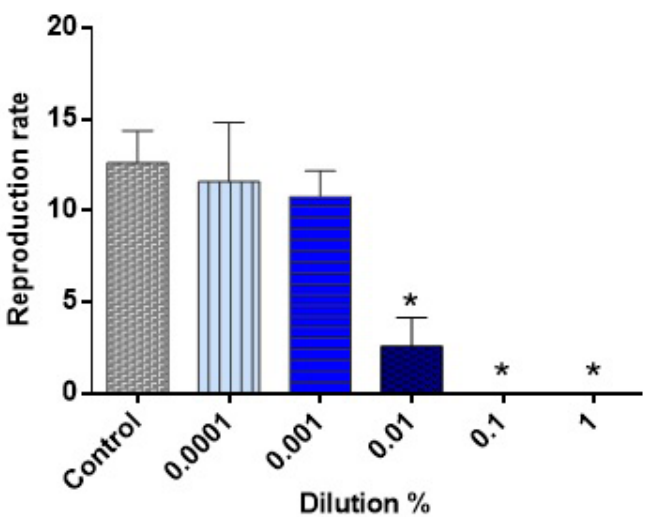

Ageofoam

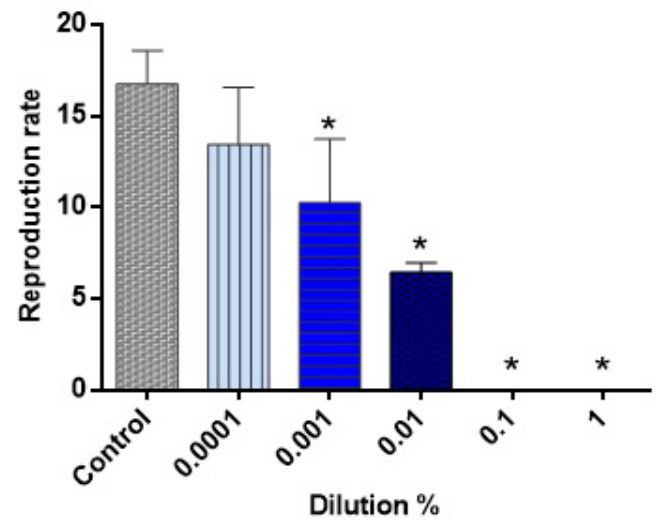

Kidde

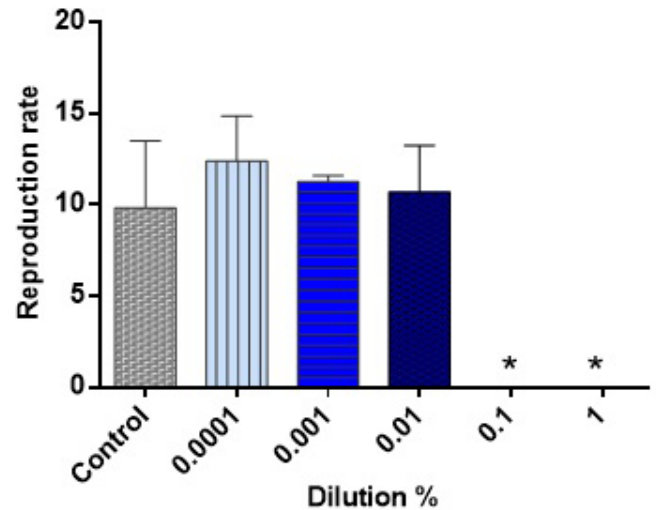

Figure 2. Reproduction rates (nauplii + copepodites/female) of the copepod Nitocra sp. exposed to different concentrations of AFFFs, with their respective standard deviations. Significant differences to the controls $(\mathrm{p}<0.05)$ are indicated by asterisks.

The obtained results evidenced that all the AFFF tested caused chronic toxicity, even when highly diluted. Among the studied AFFFs, Agefoam presented the highest toxicity to Nitocra sp. Such results may be explained based on the properties of tensoactive substances, such as the PFCs, which main effect occurs due the alteration of the permeability of cell membranes, affecting the osmotic regulation and the OD consumption. This could explain the mortality of exposed organisms, even in very low concentrations. In a recent study, Silva et al. (2019) observed high toxicity of AFFFs, including those tested in the present study, to freshwater invertebrates, in similar concentrations. On the other hand, Zhang et al. (2018) observed much lower toxicity to zebrafish, when studying 14 AFFFs from different manufacturers. The results of this study corroborate that invertebrates tend to be more sensitive to AFFFs than fish. The increase of cell membranes permeability have affected the organisms in a more intense way at the lowest dilutions ( $\geq 0.1 \%$ ), causing a faster injury of organisms (visually) in comparison with the controls. It is known that the tensoactive properties increase the permeability of soft 
tissues, increasing their degradation by means of breakage of lipid membranes (Lewis, 1992). In this case, the impacts of AFFFs to the resident biota cannot be precisely estimated, since these substances have the potential to dissolve the bodies of the animals.

The commerce of AFFFs in Brazil is not well controlled, and the commercial products are sold as they are not toxic and biodegradable materials; moreover, their recommended dilutions range according to the manufactures, but in general they range between 1 and 3\% (Table 3). However, when such dilutions are compared to the respective LOECs to Nitocra sp., it is evidenced that they are capable to cause toxic effects to the organisms; such effects occur in dilutions up to a thousand times lower than those recommended (tested dilutions of $0.001 \%$ ).

Table 3. Recommended dilutions for the tested AFFFs, according to their respective manufacturers, and their Lowest Observed Effect Concentrations (LOECs) to Nitocra sp. (in \%).

\begin{tabular}{crc}
\hline AFFF & Comercial use & \multicolumn{1}{c}{ LOEC } \\
\hline Ageofoam & $1 \%$ & $0.001 \%$ \\
Cold & 1 to $3 \%$ & $0.01 \%$ \\
Kidde & $3 \%$ & $0.1 \%$ \\
Argus & $3 \%$ & $0.1 \%$ \\
\hline
\end{tabular}

Each commercial AFFF has a complex and specific chemical composition, but the commercial formulations have a common aspect, that is the presence of several PFCs. Consequently the resulting toxicity is the synergetic effect of the different substances that are combined in the commercial formulations tested. Since many chemicals present in AFFFs contain fluorine, and that the carbon-fluorine bond is the strongest existing covalent bond $(450 \mathrm{~kJ} / \mathrm{mol})$, which is capable to resist to metabolic processes and present thermal, chemical and biological inertia (Parsons et al., 2008), their resistance to degradation may increase the persistence in the environment (Schultz et al., 2003), favoring their bioaccumulation, trophic transference and longterm toxicity. In fact, studies have demonstrated that PFCs are highly toxic to a range of organisms (Ahrens, 2011; Oakes et al., 2010; Suja et al., 2009) and can explain the high toxicity of AFFFs, as evidenced in the present study.

Montagnolli (2015) conducted a study during the Tequimar fire and showed that the AFFFs induced changes in the bacterial community found in the contaminated soils and also caused phyto-toxicity to vegetables with high economic value, such as lettuce and arugula. The diversity of bacteria was affected due to the presence of AFFFs in the estuary, according to Merguizo (2017). Despite Montagnolli (2015) has observed toxicity reduction along time and Merguizo (2017) identified an increase of the density of some bacterial strains, suggesting that the microbiota was capable to metabolize the compounds present in the AFFFs, the concentrations of PFCs did not decrease and toxicity persisted along one year after the fire (unpublished data). Thus, the high toxicity of AFFFs in the present study not only corroborates the impacts of this fire episode but also suggests that effects on the estuarine biota may be of long-term.

Chemical compounds with high potential toxicity to organisms of the basis of trophic chain may cause severe ecological disturbance in estuarine and marine environments. Adverse effects of AFFFs were also evidenced by Rotundo et al. (2015), just after the fire. These authors reported the massive mortality of 8 tons of fish, belonging to 142 species, including 15 threatened and 7 under risk of extinction. Therefore, since the present study detected very high toxicity to Nitocra sp., it is possible to explain the high impact of AFFFs on the richness and abundance of ichthyofaunal of the Santos Estuarine System during and after the fire in the petrochemical terminal. 
The appropriate disposal of these mixtures should also be standardized, in order to avoid their spill into effluents and sewage systems which are not prepared to treat and remove such substances. In Australia, there is a decontamination manual which aims to support and orientate the conduction and revision of control actions in all steps of evaluation, remediation and management (Department of Environmental and Heritage Protection, 2016). Despite that manual was developed specifically to that country, it could be used as a reference to Brazil, until national studies could provide information to the development of national protocols.

In the case of the petrochemical terminal of Aratu/ Tequimar, the magnitude and duration of the impacts caused by the use of AFFFs, together with their potential interactions with the contaminants involved in the accident, such as fuels, and also those already present in the environment, produce a scenario of high threat to the local ecosystems. Moreover, this situation makes it much more difficult to predict and understand the environmental impacts related with this event, due to the inherent complexity. Anyway, the present study shows that the release of AFFFs into the waters of the Santos Estuarine System may have caused severe effects on the aquatic biota, considering the toxicity of the AFFFs to estuarine microcrustaceans.

The results of this broad research will be useful to institutions interested on environmental conservation and management and public health, such as environmental agencies (IBAMA, CETESB), port authorities (Companhia Docas do Estado de São Paulo - CODESP), Federal and State Public Ministries, municipal authorities of the cities of Santos, Cubatão, Guarujá and São Vicente (regions directly influenced by the major fire), as well as the general public. Since AFFFs are toxic and may include POPs in their formulations (such as PFOS), this investigation can contribute to the National Plan of Implementation, which aims to plan the strategies and actions to accomplishment of the commitments of the Stockholm Convention, including the improvement of the national analytical capability, POPs monitoring, research, information dissemination and public awareness (Ministério do Meio Ambiente, 2015). Moreover, the results of this study also indicate that the commerce and use of AFFFs in Brazil are required, due to the evident toxicity to the aquatic biota. Further studies arealso recommended, considering even lower concentrations than those used in this investigation (i.e. $<0.0001 \%$ ), in order to provide the safe concentrations that do not cause negative effects to the biota. The range of studied species should be increased, in order to improve the understanding of the sub-lethal effects, determine long-term effects to other aquatic species and the environmental risks associated to AFFFs.

\section{CONCLUSIONS}

All the AFFFs were toxic in the dilutions recommended by the manufacturers to use and also in much lower concentrations. In the higher concentrations, high toxicity was observed, which was evidenced by the lethal effects to the organisms. In this sense, the release of high amounts of AFFFs in the Santos Estuarine System during the firefighting probably caused severe impacts, such as the massive fish mortality.

\section{ACNOWLEDGEMENTS}

The authors thank the National Council for Scientific and Technological Development (CNPq Conselho Nacional de Desenvolvimento Científico e Tecnológico) (Processes\#135345/2016-2; \# 311609 / 2014 - 7 ; \# 308533 / 2018 - 6 ; \#165861/2014-2;\#401261/2017-4;455280/20142) and the São Paulo Research Foundation (FAPESP - Fundação de Amparo à Pesquisa do Estado de São Paulo) (Grant \#13/15482-0) for the financial support. We are also grateful to the NEPEA staff 
for the support to the experiments, to the Regional Office of IBAMA in Santos and the Fire Department of Military Police of São Paulo State for the logistic support during this project and the supply of AFFF samples.

Conflict of interest: The authors declare that there is no conflict of interest

\section{BIBLIOGRAPHIC REFERENCES}

Abessa, D.M.S, Carr, R.S., Souza, E.C.P.M., Rachid, B., Zaroni, L.P., Gasparro, M.R., Pinto, Y.A., Bícego, M.C., Hortellani, M.A., Sarkis, J.E.S. \& Muniz, P. (2008). Integrative ecotoxicological assessment of contaminated sediments in a complex tropical estuarine system. In: T.N. Hofer (Ed.), Marine Pollution: New Research, (pp.125-159). New York, USA: Nova Science Publishers, Inc.

Ahrens, L. (2011). Polyfluoroalkyl compounds in the aquatic environment: a review of their occurrence and fate. Journal of Environmental Monitoring. 13(1): 20-31. doi: 10.1039/c0em00373e

Araújo-Castro, C., Souza-Santos, L.P., Torreiro, A.G.A., \& Garcia, K.S. (2009). Sensitivity of the marine benthic copepod Tisbe biminiensis (Copepoda, Harpacticoida) to potassium dichromate and sediment particle size. Brazilian Journal of oceanography. 57 (1): 33-41. doi: http://dx.doi. org/10.1590/S1679-87592009000100004

Azevedo, F.A. \& Chasin, A.A.M. (2003). As bases toxicológicas da ecotoxicologia. São Paulo: RiMa Editora. 340p.

Beach, S.A., Newsted, J.L., Coady, K. \& Giesy, J.P. (2006). Ecotoxicological evaluation of perfluorooctane sulfonate (PFOS). Reviews of Environmental Contamination and Toxicology. 186: 133-174. doi: https://doi.org/10.1007/0-387-32883-1_5

Benford, D., De Boer, J., Carere, A., Di Domenico, A., Johansson, N., Schrenk, D. \& Dellatte, E. (2008). Opinion of the scientific panel on contaminants in the food chain on perfluorooctane sulfonate (PFOS), perfluorooctanoic acid (PFOA) and their salts. EFSA Journal. 653: 1-131. doi: https://doi.org/10.2903/j. efsa.2008.653
Birge, W.J., Black, J.A \& Westerman, A.G. (1985). Shortterm fish and amphibian embryo-larval tests for determining the effects of toxicant stress on early life stages and estimating chronic values for single compounds and complex effluents: Complex mixtures. Environmental Toxicology and Chemistry. 4 (6): 807-821. doi: https://doi.org/10.1002/ etc. 5620040612

Buruaem, L. B., Rosa, P.A., Araujo, G.S., Nicodemo, S.C.T.S., Oporto, V.F., Fonseca, J.R., Cruz, J.V.F., Medeiros, G.F. \& Abessa, D.M.S. (2013). Assessment of sediment toxicity from the Areia Branca off-shore harbor and the Potengi river estuary (RN), Northeastern Brazil. Pan-American Journal of Aquatic Sciences. 8 (4): 312-326.

Cariello, M.S. (2018). Efeito do naftaleno na microalga marinha Dunaliella tertiolecta, ouriço-do-mar Lytechinus variegatus e no microcrustáceos estuarinos Nitokra sp e Leptocheirus plumulosus Doctoral Thesis, Universidade de São Paulo, Instituto Oceanográfico. São Paulo, SP. 127p. Retrieved from https://www.teses.usp.br/teses/ disponiveis/21/21134/tde-10122012-165258/ publico/MarianaStefanonCariello.pdf

Cesar, A., Da Silva, S.L, \& Ramos-Santos, A. (1997). Testes de toxicidade aquática no controle da poluição. Retrieved from https://www.unisanta.br/ arquivos/apostilaecotox.pdf

De Paiva Magalhães, D., \& Da Silva Ferrao Filho, A. (2008). Ecotoxicology as a tool to monitoring aquatic ecosystems. Oecologia Australis. 12 (3): $355-381$.

Department of Environmental and Heritage Protection - DEHP. (2016). Environmental Management of Firefighting Foam Policy - Explanatory Notes Revision 2. Retrieved from https://environment.des. qld.gov.au/_data/assets/pdf_file/0022/89140/ firefighting-foam-policy-notes.pdf

GT - CREA /SP. (2015). Estudo de Implementação das Recomendações da "Carta de Santos - 2015" Retrieved from http://www.abtl.org.br/wpcontent/themes/abtl/arquivos/GT\%20-\%20 INCÊNDI0\%20ALEMOA\%20-\%20RELATÓRI0\%20 FINAL\%20-\%20Versão\%20final\%2019.07.16.pdf

Hoff, P.T., Campenhout, K.V., Van De Vijver, K., Covaci, A., Bervoets, L., Moens, L., Huyskens, G., Goemans, G., Belpaire, C., Blust, R. \& De Coen,W. (2005). Perfluorooctane sulfonic acid and organohalogen pollutants in liver of three freshwater fish species in 
Flanders (Belgium): relationships with biochemical and organismal effects. Environmental Pollution. 137: 324-333 doi: https://doi.org/10.1016/J. ENVPOL.2005.01.008

Instituto Brasileiro do Meio Ambiente e dos Recursos Naturais Renováveis - IBAMA (2016). Ofício 02027.000773/2016-99 ESREG SANTOS/SP/ IBAMA. Santos, SP, Brasil: IBAMA. 3p.

Izar, G.M., Morais, L.G., Pereira, C.D.S., Cesar, A., Abessa, D.M.S., Christofoletti, R.A. (2019). Quantitative analysis of pellets on beaches of the São Paulo coast and associated non-ingested ecotoxicological effects on marine organisms. Regional Studies in Marine Science. 29. doi: https://doi.org/10.1016/j. rsma.2019.100705

Lamparelli, M.C., Costa, M.P.D., Prósperi, V.A., Bevilacqua, J.E., Araújo, R.P.D.A., Eysink, G. G.J. \& Pompéia, S. (2001). Sistema Estuarino de Santos e São Vicente. Retrieved from https://cetesb.sp.gov.br/praias/ wp-content/uploads/sites/31/2013/11/relatorio. zip

Lewis, M.A. (1992). The effects of mixtures and other environmental modifying factors on the toxicities of surfactants to freshwater and marine life. Water Research. 26 (8): 1013-1023. doi: https://doi. org/10.1016/0043-1354(92)90136-R

Lotufo, G.R. \& Abessa, D.M.S. (2002). Testes de toxicidade com sedimento total e água intersticial estuarinos utilizando copépodos bentônicos. In: Nascimento, I.A., Sousa, E,C.P.M. \& Nipper, M. (orgs). Métodos em ecotoxicologia marinha: aplicações para o Brasil. pp.151-162. São Paulo, SP, Brasil: Artes Gráficas e Industriais.

Luebker, D.J., Hansen, K.J., Bass, N.M, Butenhoff, J.L. \& Seacat, A.M. (2002). Interactions of fluorochemicals with rat liver fatty acid-binding protein. Toxicology. 176 (3): 175-185. doi: https://doi.org/10.1016/ s0300-483x(02)00081-1

Maciel, D.C., Costa, B.V.M., Souza Santos, L.P., Souza, J.R.B., \& Zanardi-Lamardo, E. (2015). Avaliação da toxicidade dos sedimentos do sistema estuarino do Rio Capibaribe (Pernambuco, Brasil) utilizando o copépodo bentônico Tisbe biminiensis Volkmann Rocco (1973). Tropical Oceanography. 43 (1): 26-37. doi: https://doi.org/10.5914/tropocean. v43i1.5882
Maranho, L.A., Seabra, C.D, Choueri, R.B, Cesar, A., Gusso-Choueri, P.K., Torres, R.J., De Souza Abessa, D.M., Morais, R.D., Mozeto, A.A., DelVallsa, T.A. \& Martín-Díazab, M.L. (2012). The application of biochemical responses to assess environmental quality of tropical estuaries: field surveys. Journal of Environmental Monitoring. 14 (10): 2608-2615. doi: http://dx.doi.org/10.1039/c2em30465a

Merguizo, R. (2017). Diversidade e sucessão bacteriana em sedimentos contaminados por hidrocarbonetos, derivados e por dispersão de espumas para controle de incêndio (AFFF), no Estuário de Santos-SP. Retrieved from http://hdl.handle. net/11449/148802

Ministério do Meio Ambiente (2015). Plano Nacional de Implementação Brasil. Convenção de Estocolmo. Ministério do Meio Ambiente (MMA).192 p. Retrieved from http://www.mma.gov.br/images/ arquivo/80037/Convenca0\%20de\%20Estocolmo/ Plano\%20de\%20Implementacao\%20NIP/Plano_ NIP_Ingles_impressao_final.pdf

Montagnolli, R. (2015). Incêndios de petróleo e petroquímicos: biorremediação de áreas afetadas. Retrieved from http://hdl.handle. net/11449/134062

Moody, C.A. \& Field, J.A. (2000). Perfluorinated surfactants and the environmental implications of their use in fire-fighting foams. Environmental Science \& Technology. 34 (18): 3864-3870. doi: https://doi.org/10.1021/es991359u

Murakami, M., Imamura, E., Shinohara, H., Kiri, K., Muramatsu, Y., Harada, A. \& Takada, H. (2008). Occurrence and sources of perfluorinated surfactants in rivers in Japan. Environmental science \& technology. 42(17): 6566-6572. doi: http://dx.doi. org/10.1021/es800353

Oakes, K.D., Benskin, J.P., Martin, J.W., Ings, J.S., Heinrichs, J.Y., Dixon, D.G., Servos, M.R. (2010). Biomonitoring of perfluorochemicals and toxicity to the downstream fish community of Etobicoke Creek following deployment of aqueous film-forming foam. Aquatic Toxicology. 98 (2): 120-129. doi: https://doi.org/10.1016/j.aquatox.2010.02.005 
Organisation for Economic Cooperation and Development - OECD (2007). Validation report of the full life-cycle test with the harpacticoid copepods Nitocra spinipes and Amphiascus tenuiremis and the calanoid copepod Acartia tonsa - phase 1. Series No. 79. Paris, France: OECD.

Parsons, J.R., Saez, M., Dolfing, J. \& De Voogt, P. (2008). Biodegradation of perfluorinated compounds. Reviews of Environmental Contamination and Toxicology. 196 (1): 53-71. doi: http://dx.doi. org/10.1007/978-0-387-78444-1_2

Perina, F.C., Torres, R.J., Mozeto, A.A., Nascimento, M.R.L. \& Abessa, D.M.S. (2018). Sediment quality assessment of the tributaries of the Santos-São Vicente Estuarine System - Brazil Ecotoxicol. Environ. Saf. 13 (99-106): 25-38

Post, G.B., Perry, D.C., \& Cooper, K.R. (2012). Perfluorooctanoic acid (PFOA), an emerging drinking water contaminant: a critical review of recent literature. Environmental research. 116: 93117. doi: 10.1016/j.envres.2012.03.007

Ramade, F. (1977). Ècotoxicologie. Paris, France: Masson. 205p

Régis, C.G., Souza-Santos, L.P., Yogui, G.T., Moraes, A.S., \& Schettini, C.A.F. (2018). Use of Tisbe biminiensis nauplii in ecotoxicological tests and geochemical analyses to assess the sediment quality of a tropical urban estuary in northeastern Brazil. Marine pollution bulletin. 137: 45-55. doi: 10.1016/j. marpolbul.2018.10.011

Rotander, A., Toms, L.M.L., Aylward, L., Kay, M., \& Mueller, J.F. (2015). Elevated levels of PFOS and PFHxS in firefighters exposed to aqueous film forming foam (AFFF). Environment international. 82: 28-34. doi: https://doi.org/10.1016/j.envint.2015.05.005

Rotundo, M.M., Laranjeira, M.E., Cardoso, G.S., Gama, L.M., Souza, U.P., Ferreira, F.C., Barrella, W., Ramires, M., Clauzet, M. \& Petrere Jr, M. (2015). Incêndio na área portuária de Santos (SP): impacto sobre a diversidade de peixes. Retrieved from http:// www.seb-ecologia.org.br/revistas/indexar/anais/ xiiceb/pdf/392.pdf

Ruppert, E.E., Fox, R.S. \& Barnes, R.D. (1996). Zoologia dos invertebrados. 6. Ed. São Paulo: Editor Roca. $1088 p$
Schultz, M.M., Barofsky, D.F. \& Field, J.A. (2003). Fluorinated alkyl surfactants. Environmental Engineering Science. 20(5): 487-501. doi: https:// doi.org/10.1089/109287503768335959

Sikder, M., Eudy, E., Chandler, G. T., \& Baalousha, M. (2018). Comparative study of dissolved and nanoparticulate Ag effects on the life cycle of an estuarine meiobenthic copepod, Amphiascus tenuiremis. Nanotoxicology. 12 (5): 375-389

Siqueira, G.W., Braga, E.S., Mahíques, M.M., \& Aprile, F.M. (2006). Determinação da Matéria Orgânica e Razões $\mathrm{C} / \mathrm{Nec} / \mathrm{S}$ em Sedimentos de Fundo do Estuário de Santos-SP/Brasil. Arquivos de Ciências do Mar. 39112): 18-2. doi: https://doi.org/10.32360/acmar. v39i1-2.6153

Silva, S.C., Pusceddu, F.H., Ortega, A.S.B., Abessa, D.M.S., Pereira, C.D.S. \& Maranho, L.A. (2019). Aqueous Film-Forming Foams (AFFFs) are very toxic to aquatic microcrustaceans. Water, Air, \& Soil Pollution. 230(11): 260. doi: https://doi. org/10.1007/s11270-019-4291-x

Secretaria do Meio Ambiente do Estado de São Paulo. (2013). Zoneamento ecológico-econômico (ZEE)setor costeiro da Baixada Santista. Retrieved from:http://arquivos.ambiente.sp.gov.br/ cpla/2011/05/ZEE_PUBLICACA0.pdf

Smithwick, M., Mabury, S.A., Solomon, K.R., Sonne, C., Martin, J.W., Born, E.W., Dietz, R., Derocher, A.E., Letcher, R.J., Evans, T.J., Gabrielsen, G.W., Nagy, J., Stirling, I., Taylor, M.K. \& Muir, D.C.G. (2005). Circumpolar study of perfluoroalkyl contaminants in polar bears (Ursus maritimus). Environmental science \& technology. 39(15): 5517-5523. doi: https://doi.org/10.1021/es048309w

Suja, F., Pramanik, B.K. \& Zain, S.M. (2009). Contamination, bioaccumulation and toxic effects of perfluorinated chemicals (PFCs) in the water environment: a review paper. Water Science \& Technology. 60 (6): 1533 - 1544. doi: https://doi. org/10.2166/wst.2009.504

Tao, L., Kannan, K., Kajiwara, N., Costa, M. M., Fillmann, G., Takahashi, S., \& Tanabe, S. (2006). Perfluorooctanesulfonate and related fluorochemicals in albatrosses, elephant seals, penguins, and polar skuas from the Southern Ocean. Environmental science \& technology. 40 (24):76427648. doi: https://doi.org/10.1021/es061513u 
Toms, L. M., Thompson, J., Rotander, A., Hobson, P., Calafat, A. M., Kato, K., Ye, X., Broomhall, S., Harden, F. \& Mueller, J. F. (2014). Decline in perfluorooctane sulfonate and perfluorooctanoate serum concentrations in an Australian population from 2002 to 2011. Environment international. 71: 74-80. doi: 10.1016/j.envint.2014.05.019

Van de Vijver, K.I., Hoff, P.T., Van Dongen, W., Esmans, E.L., Blust, R. \& De Coen, W.M. (2003). Exposure patterns of perfluorooctane sulfonate in aquatic invertebrates from the Western Scheldt estuary and the southern North Sea. Environmental Toxicology and Chemistry. 22: 2037-2041. doi: https://doi. org/10.1897/02-385

Zhang, X., Bao, Z., Fu, X., Hu, C. \& Jing, L. (2018). Acute toxicity of aqueous film forming foam (AFFF) to zebrafish (Brachydanio rerio). IOP Conference Series: Earth and Environmental Science. 199: 1755-1315. doi: https://doi.org/10.1088/1755$1315 / 199 / 3 / 032010$ 